\title{
PENGARUH MODAL KERJA, NILAI UPAH, DAN TEKNOLOGI TERHADAP PENYERAPAN TENAGA KERJA PADA INDUSTRI KERAJINAN SERAT AGEL DI DESA SALAMREJO
}

\author{
Oleh \\ Uwi Martayadi ${ }^{1)}$ \& Dyah Indraswati ${ }^{2)}$ \\ 1Program Studi Pariwisata, Sekolah Tinggi Pariwisata Mataram \\ ${ }^{2}$ Pendidikan Guru Sekolah Dasar, FKIP, Universitas Mataram \\ Email: ${ }^{1}$ uwimartayadistp@gmail.com \& 2 dyahindraswati@unram.ac.id
}

\begin{abstract}
The objectives to be achieved in this research are to 1). Knowing the effect of working capital on labor absorption 2). Knowing the effect of wages on labor absorption 3). Knowing the effect of technology on labor absorption 4). Knowing the effect of working capital, wage value and technology simultaneously on the absorption of labor in the agel fiber handicraft industry in Salamrejo Village, Sentolo District, Kulon Progo. This type of research is Expost Facto research. This research is causal associative because it looks for the influence of independent variables on the dependent variable. The population in this study were all agel fiber handicraft entrepreneurs in the village of Salamrejo, which according to the head of the development division in the village of Salamrejo were 30 entrepreneurs. The data collection methods used questionnaires, interviews, and documentation. The analysis used is multiple linear regression. The results showed that there was a positive and significant influence between working capital on labor absorption. There is a positive and significant influence between the value of wages on labor absorption. There is a positive and significant influence between technology on labor absorption. There is a positive and significant influence between working capital, wages and technology simultaneously on labor absorption in Salamrejo Village in December 2019.
\end{abstract}

Keywords: Working Capital, Wage Value, Technology \& Labor Absorption

\section{PENDAHULUAN}

Kondisi ekonomi Indonesia yang terpuruk saat terjadinya krisis ekonomi tahun 1997-1998 memberikan gambaran kepada kita bahwa disaat banyak perusahaan besar bangkrut, UMKM (Usaha Mikro, Kecil dan Menengah) mampu tetap berdiri kokoh (Oktafia, 2017). Karakteristik UMKM meliputi berskala mikro, tersebar di seluruh wilayah Indonesia, padat karya, relative kecil investasi tetapi mampu menghasilkan nilai tambah yang tinggi, menggunakan teknologi yang sederhana sampai madya, dan terkadang tidak memerlukan skill yang tinggi, dapat menciptakan wirausaha baru, memiliki fleksibilitas yang tinggi dalam mengantisipasi perubahan pasar dan tahan terhadap gejolak krisis ekonomi (Widiastuti, R*; Awang, S.A**; Prayitno, T.A. **, Warsito, 2011). Pada tahun 2009, kontribusi UMKM terhadap PDB
Indonesia mencapai sekitar $45 \%$ atau senilai Rp. 2.000 triliun. Pada tahun 2009 UMKM juga mampu menyerap 91,8 juta tenaga kerja di Indonesia. Pada tahun 2010 jumlah UMKM mencapai 52,2 juta unit usaha yang tersebar di seluruh wilayah Indonesia (Rudiantoro \& Siregar, 2012).

Peningkatan jumlah penduduk memberikan konsekuensi pertambahan jumlah Angkatan kerja (Setyowati, 2009). Angkatan kerja yang memiliki pertumbuhan lebih cepat dibandingkan kesempatan kerja akan menambah jumlah pengangguran (Dimas, 2009). Banyaknya UMKM sangat berpotensi menyerap tenaga kerja di Indonesia (Suci, 2017). Jumlah UMKM di provinsi Daerah Istimewa Yogyakarta menurut bappeda.jogjaprov.go.id pada tahun 2019 mencapai 262.130 unit dan mampu menyerap tenaga kerja sebesar 668.214 orang. Kulon 
progo sebagai salah satu kabupaten di provinsi DIY mencatat jumlah penduduk usia kerja pada tahun 2019 sebesar 334.596 orang, sedangkan jumlah Angkatan kerja pada tahun 2019 sebesar 256.632 orang. Jumlah penduduk berumur 15 Tahun ke Atas yang menganggur pada tahun 2019 sebesar $4.614 \quad$ orang (kulonprogokab.bps.go.id). Salah satu industry di Kabupaten Kulon Progo yang potensial dalam penyerapan tenaga kerja adalah industry kerajinan serat agel. Industri ini cukup berkembang di Desa Salamrejo, Sentolo, Kulon Progo. Industri kerajinan serat agel di Desa Salamrejo mampu menyerap \pm 900 tenaga kerja. Industri kerajinan serat agel merupakan salah satu industry manufaktur yang mengolah bahan mentah atau produk setengah jadi menjadi produk jadi sehingga lebih bernilai ekonomis (Nurin Haq Swarsingkin, 2015).

Menurut salah satu pegawai di salah satu sentra industry serat agel di Desa Salamrejo, Kulon Progo, serat agel didapat dari daun pohon gebang yang merupakan salah satu varian pohon palem. Serat pohon gebang ini dipakai untuk membuat berbagai macam produk seperti tas, topi, dompet, karpet, taplak meja, dan sebagainya. Sentra produksi serat agel di Kulon Progo selain mampu menyerap tenaga daerah sekitar juga mampu memasarkan hasil kerajinannya ke berbagai negara seperti Amerika Serikat, Taiwan, Malaysia, Belanda, Australia, dan sebagainya. Kerajinan serat agel ini dihasilkan dengan keterampilan tangan sehingga menjadi barang yang fungsional dan bernilai ekonomi tinggi (Pandansari, Handajani, \& Pamungkas, 2015).

Setiap industri pasti memiliki perhitungan tentang modal kerja, nilai upah, dan teknologi yang digunakan. Modal kerja merupakan keseluruhan aktiva lancar yang dimiliki oleh perusahaan atau dapat pula diartikan sebagai dana yang harus tersedia untuk membiayai operasional perusahaan. Bentuk aktiva lancar dapat berupa kas, piutang, persediaan, dan surat-surat berharga (Azlina, 2012). Upah merupakan sejumlah pengeluaran perusahaan yang diperuntukkan untuk membayar tenaga kerja karena sudah melakukan pekerjaannya. Perubahan tingkat upah akan mempengaruhi biaya produksi perusahaan. Banyak industry kecil di Indonesia hanya perupaya bertahan dengan pangsa pasar yang masih terbatas dan hasil produksi terbatas. Suatu beban tersendiri bagi mereka memberikan upah sesuai Upah Minimum Regional (UMR) atau Upah Minimum Kabupaten (UMK) (Putra, 2012). Teknologi dapat dipandang sebagai ilmu pengetahuan, sebagai benda, sebagai proses, dan sebagai control. Teknologi memiliki tiga domain yaitu teknologi perancangan, teknologi produksi, dan teknologi pemasaran (Sumarno, 2010). Teknologi yang digunakan di Industri kerajinan serat agel di Desa Salamrejo masih sangat sederhana, menurut pengakuan ibu Isti Rahayu, semua proses pembelahan, pewarnaan, pengeringan, perajutan masih manual sehingga banyak membutuhkan tenaga manusia. Penelitian yang dilakukan oleh Agnes Febriana, dkk membuktikan modal, tingkat upah, dan teknologi berpengaruh positif dan signifikan terhadap penyerapan tenaga kerja di Industri kerajinan batako di Kecamatan Mengwi, Kabupaten Badung, Provinsi Bali (Putri \& Kesumajaya, 2017). Peneliti ingin mengetahui apakah hasil tersebut juga berlaku pada kerajinan serat agel yang terdapat di Desa Salamrejo, Kecamatan Sentolo, Kulon Progo.

Tujuan yang akan dicapai dalam penelitian ini adalah untuk: 1). Mengetahui pengaruh modal kerja terhadap penyerapan tenaga kerja 2). Mengetahui pengaruh nilai upah terhadap penyerapan tenaga kerja 3). Mengetahui pengaruh teknologi terhadap penyerapan tenaga kerja 4). Mengetahui pengaruh modal kerja, nilai upah dan teknologi secara simultan terhadap penyerapan tenaga kerja pada Industri kerajinan serat agel di Desa Salamrejo, Kecamatan Sentolo, Kulon Progo.

\section{METODE PENELITIAN}

Jenis penelitian ini adalah penelitian Expost Facto yang merupakan jenis penelitian yang kejadiannya sudah terjadi sebelum penelitian ini dilaksanakan (Sappaile, 2010). Penelitian ini bersifat asosiatif kausal karena mencari pengaruh variabel bebas terhadap 
variabel terikat. Penelitian ini dilaksanakan pada bulan Januari 2020 sampe selesai. Populasi dalam penelitian ini adalah seluruh pengusaha kerajinan serat agel di Desa Salamrejo yang menurut kepala bagian pembangunan di Desa Salamrejo berjumlah 30 pengusaha yang apabila ditotal memiliki \pm 900 orang tenaga kerja. Pengusaha industry kerajinan terdiri dari 12 orang laki-laki dan 18 orang perempuan. Metode pengumpulan data menggunakan angket, wawancara, dan dokumentasi. Angket yang dipergunakan adalah angket terbuka yang berjumlah 36 butir pertanyaan. Analisis yang dipergunakan adalah regresi linier berganda yang digunakan untuk menganalisis pengaruh variabel modal kerja (X1), nilai upah (X2), teknologi (X3) terhadap penyerapan tenaga kerja $(\mathrm{Y})$.

\section{Gambar 1. Kerangka Berpikir}

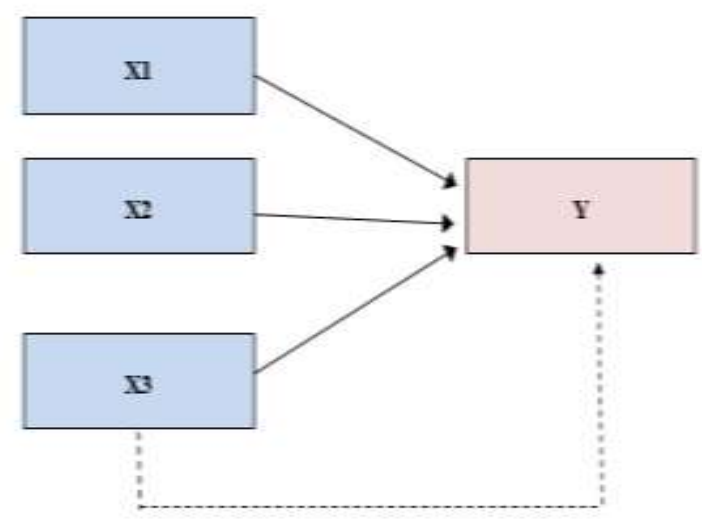

Sumber: (Indraswati, Hidayati, Wulandari, \& Maulyda, 2020)

Keterangan:

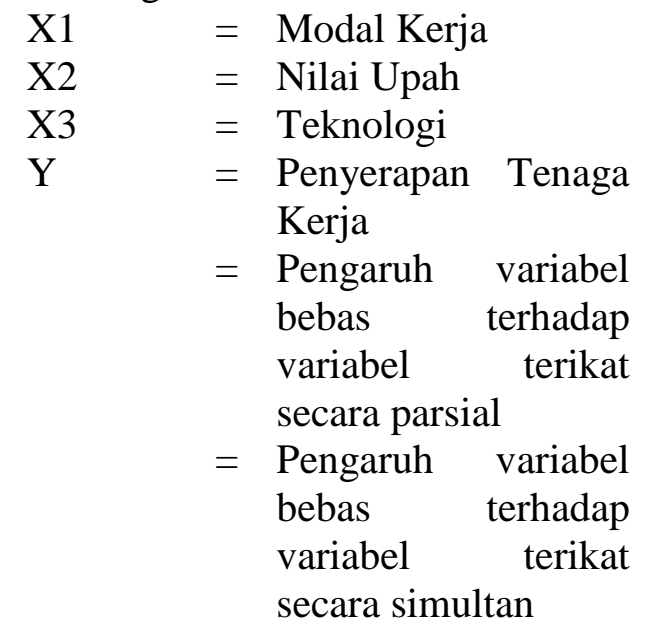

Tabel 1. Indikator Variabel Penelitan

\begin{tabular}{|c|c|c|c|}
\hline No. & $\begin{array}{l}\text { Variabel } \\
\text { Penlitian } \\
\end{array}$ & $\begin{array}{l}\text { Indikator } \\
\end{array}$ & Nomor butir \\
\hline 1. & Modal Kerja & $\begin{array}{ll} & \text { Modal awal } \\
\text { - } & \text { Kas } \\
\text { Omset penjualan pada } \\
\text { bulan Desember } 2019 \\
\text { - } & \text { Persediaan bahan baku } \\
& \text { pada bulan Desember } \\
& 2019 \\
\text { - } & \text { Jumlah barang yang } \\
& \text { diproduksi pada bulan } \\
& \text { Desember 2019 } \\
\text { - } & \text { Biaya pengeluaran pada } \\
& \text { bulan Desember 2019 } \\
\text { - } & \text { Keuntungan pada bulan } \\
& \text { Desember 2019 }\end{array}$ & $\begin{array}{c}1,2,3,4 \\
5 \\
6 \\
\\
7,8,9,10,11,12 \\
13,14,15 \\
16,17,18,19,20\end{array}$ \\
\hline 2. & Nilai Upah & $\begin{array}{ll}\text { - } & \text { Upah pada bulan } \\
& \text { Desember } 2019 \\
\text { - } & \text { Tunjangan tenaga kerja } \\
\text { pada bulan Desember } \\
2019 \\
\text { - } \\
\text { Bonus tenaga kerja pada } \\
\text { bulan Desember 2019 } \\
\end{array}$ & $\begin{array}{l}22 \\
23 \\
24\end{array}$ \\
\hline & Teknologi & $\begin{array}{ll} & \text { Peralatan dalam } \\
& \text { pengolahan serat agel } \\
\text { - } & \text { biaya aplikasi teknologi } \\
& \text { dalam pengolahan serat } \\
\text { agel pada bulan Desember } & 2019\end{array}$ & 25,26 \\
\hline 4. & $\begin{array}{l}\text { Penyerapan } \\
\text { tenaga kerja }\end{array}$ & $\begin{array}{ll}\text { - Jumlah tenaga kerja pada } \\
\text { saat pendirian } \\
\text { - Jumlah jam kerja } \\
\text { - Jumlah tenaga kerja tetap } \\
\text { pada bulan Desember } \\
2019 \\
\text { - Jumlah tenaga kerja tidak } \\
\text { tetap pada bulan } \\
\text { Desember } 2019 \\
\text { - Total tenaga kerja pada } \\
\text { bulan Desember } 2019 \\
\text { - Jumlah tenaga kerja laki- } \\
\text { laki pada bulan Desember } \\
\text { 2019 } \\
\text { - Jumlah tenaga kerja } \\
\text { perempuan pada bulan } \\
\text { Desember 2019 } \\
\text { - Pendidikan tertinggi } \\
\text { Tenaga Kerja }\end{array}$ & $\begin{array}{c}33 \\
34 \\
35,36\end{array}$ \\
\hline
\end{tabular}

\section{HASIL DAN PEMBAHASAN}

\section{Deskripsi Hasil Penelitian}

a. Kondisi Geografis Daerah Penelitian

Desa Salamrejo adalah sebuah kelurahan yang terletak di Kecamatan Sentolo, Kabupaten Kulon Progo, Provinsi Daerah Istimewa Yogyakarta dengan luas wilayah sebesar 421.362 ha. Desa Salamrejo terletak $13 \mathrm{~km}$ dari Ibukota Kabupaten dan $20 \mathrm{~km}$ dari Ibukota provinsi. Secara geografis Desa Salamrejo terbagi menjadi 8 wilayah dusun antara lain: dusun Klebaan, dusun Mentobayan, dusun Giyoso, dusun Karangwetan, dusun Kidulan, dusun Dhisil, dusun Salam, dan dusun Ngrandu. 
Gambar 2. Peta Desa Salamrejo, Kecamatan Sentolo, Kulon Progo

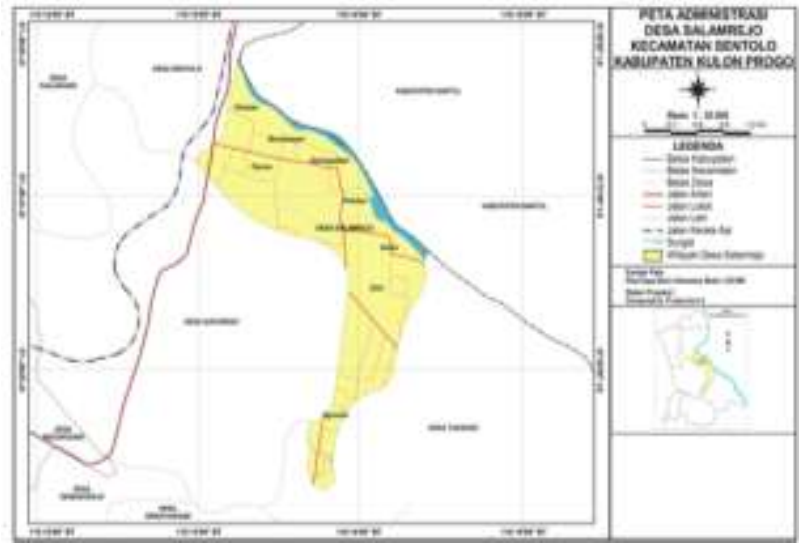

Sumber: Data Desa Salamrejo, 2019

Tabel 2. Tata Guna Lahan Desa Salamrejo

\begin{tabular}{|l|c|c|}
\hline $\begin{array}{c}\text { Jenis } \\
\text { Penggunaan } \\
\text { Lahan }\end{array}$ & $\begin{array}{c}\text { Luas } \\
(\mathbf{H a})\end{array}$ & $\begin{array}{c}\text { Persentase } \\
(\boldsymbol{\%})\end{array}$ \\
\hline $\begin{array}{l}\text { Pemukiman/ } \\
\text { perumahan }\end{array}$ & 33,750 & 24,58 \\
\hline $\begin{array}{l}\text { Sawah dan } \\
\text { ladang }\end{array}$ & 81,745 & 59,53 \\
\hline Jalan & 16,315 & 11,88 \\
\hline $\begin{array}{l}\text { Bangunan } \\
\text { Umum }\end{array}$ & 0,3929 & 0,29 \\
\hline Jalur Hijau & 0,4 & 0,29 \\
\hline Perkuburan & 3,665 & 2,67 \\
\hline Lain-lain & 1,039 & 0,76 \\
\hline \multicolumn{1}{|c|}{ Jumlah } & 137,3069 & 100 \\
\hline
\end{tabular}

Sumber: Data Desa Salamrejo, 2019

\section{b. Latar Belakang Industri Kerajinan Serat Alam di Desa Salamrejo}

Desa Salamrejo tidak hanya memproduksi barang-barang dari enceng gondok tetapi juga dari pohon gebang (agel). Pada awalnya masyarakat Desa Salamrejo mengolah agel menjadi bagor (karung) atau dijual berupa tali agel. Setelah mendapat pembinaan dari Dinas Perindustrian DIY pada tahun 1987, agel dapat dimanfaatkan menjadi aneka kerajinan dengan nilai ekonomi tinggi seperti tas, topi, alas meja, hingga tempat lampu yang siap dipasarkan. Aneka kerajinan tangan dari serat agel ini banyak diproduksi oleh tangan-tangan terampil dari Salamrejo. Para pengrajin serat alam bernaung di beberapa kelompok kerajinan (craft). Pohon gebang merupakan sejenis pohon palem yang lebih besar dan lebih kuat daun-daunnya. Pohon ini tumbuh liar pada daerah kering dan berbatu. Peralatan yang digunakan dalam proses produksi pada industry kerajinan serat alam antara lain: alat rajut, mesin jahit, gunting, jarum, panic, pisau, mesin gerinda, kompresor, mesin bor, dan mesin potong logam.

Proses produksi industry kerajinan serat agel dari tahap awal produksi sampai menjadi barang jadi adalah sebagai berikut:

1) Pohon gebang diambil daunnya yang masih muda setengah bagian, yang setengahnya lagi ditinggal untuk pertumbuhan pohonnya.

2) Daun dipisahkan dari lidinya yang kemudian lembaran daun tersebut dibelah menjadi tiga bagian. Bagian pertama menjadi agel, bagian kedua menjadi gajih, bagian ketiga tidak dapat dimanfaatkan, dan lidinya dikumpulkan untuk dibuat menjadi sapu lidi.

3) Agel tersebut dikeringkan kurang lebih 2 hari, setelah kering dipilin atau digulung seperti tampar, tetapi ukurannya lebih kecil, yang oleh warga Desa Salamrejo dinamakan tampar agel.

4) Proses pemutihan tampar agel dengan menggunakan $\mathrm{H}_{2} \mathrm{O}_{2}$.

5) Tampar agel kemudian dipanaskan dalam larutan pewarna. Setelah dua sampai tiga jam diangkat, ditiriskan, dan dijemur.

6) Proses selanjutnya tampar agel yang sudah benar-benar kering dianyam atau direnda.

7) Penempatan anyaman pada cetakan yang berbentuk seperti tas, dompet, dan topi sesuai dengan desainnya masing-masing.

8) Pengecekan kualitas untuk mengetahui apakah anyaman sudah cukup baik dan kuat serta sesuai dengan cetakan.

9) Setelah penganyaman selesai, diberi aksesoris, pemasangan hamdle, furing, dan resleting.

10) Pengecekan kualitas dan pemberian anti jamur.

11) Pengemasan dan pemasangan label. Demikianlah, proses produksi telah selesai dan siap untuk dipasarkan.

\section{c. Karakteristik Pengusaha Industri Kerajinan Serat Agel di Desa Salamrejo}

Sebagian besar pengusaha industry kerajinan serat agel berusia 41-50 tahun yaitu sebanyak 18 pengusaha, Pengusaha yang berusia 30-40 tahun ada sekitar 9 pengusaha, 
pengusaha yang berumur 51-60 tahun berjumlah 2 orang dan pengusaha yang berusia $\geq 71$ sebanyak 1 orang. Pendidikan pengusaha industry kerajinan serat agel adalah SD sebanyak 1 pengusaha, SMP sebanyak 10 pengusaha, SMA sebanyak 18 pengusaha, dan perguruan tinggi sebanyak 1 orang pengusaha. Lama usaha pengusaha industry kerajinan serat agel di Desa Salamrejo 3-10 tahun sebanyak 10 pengusaha, 11-18 tahun sebanyak 14 pengusaha, 19-26 tahun sebanyak 6 pengusaha.

Tujuan utama pengusaha industry kerajinan serat agel dalam mendirikan usaha adalah 24 pengusaha mengaku pendapatan dan keuntungan menjadi prioritas utama mereka, 4 pengusaha mendirikan usaha untuk menyerap tenaga kerja, dan 2 pengusaha mengaku sangat menyukai seni kerajinan. Berdasarkan latar belakang mendirikan usaha 4 pengusaha mengaku mendirikan usaha karena pada awalnya mengikuti pelatihan dan mencoba apa yang sudah diajarkan. 24 pengusaha mengaku karena motivasi dalam diri sendiri untuk membentuk usaha baru. Sisanya 2 pengusaha mengaku meneruskan usaha orang tuanya. Berdasarkan kepemilikan usaha, 28 responden mengaku usaha adalah milik sendiri sedangkan 2 responden mengaku usahanya adalah milik orang tua.

Besarnya modal awal untuk pengadaan mesin dan peralatan saat industry kerajinan serat agel berdiri adalah sebesar 15 pengusaha mengeluarkan modal kurang dari 900.000 rupiah, sebanyak 9 pengusaha mengaku modal awal mereka antara 1.000.000 - 1.900.000, 4 pengusaha mengaku modal awal mereka berkisar antara 3.000.000 - 4.000.000, dan 1 orang mengaku modalnya mencapai lebih dari 5.000.000 rupiah. Pada bulan Desember 2019 omset penjualan setiap pengusaha industry kerajinan serat agel mencapai lebih dari 30.000.000 rupiah.

Pengadaan bahan baku dengan cara membeli bahkan di datangkan dari Semarang, Pasuruan, Tuban, Banyuwangi, dan Klaten apabila masih dirasa kurang. Rata-rata kebutuhan bahan baku per bulan mencapai 1 kuintal.
Tabel 3. Jumlah Produksi Industri Kerajinan Serat Agel di Desa Salamrejo Pada Bulan Desember 2019

\begin{tabular}{|c|c|c|c|}
\hline No. & $\begin{array}{c}\text { Jumlah Produksi } \\
\text { (unit) }\end{array}$ & Frekuensi & $(\%)$ \\
\hline 1. & $70-880$ & 25 & 83,33 \\
\hline 2. & $890-1700$ & 0 & 0 \\
\hline 3. & $1710-2520$ & 1 & 3,33 \\
\hline 4. & $2530-3250$ & 2 & 6,67 \\
\hline 5. & $3350-4070$ & 1 & 3,33 \\
\hline 6. & $4170-5000$ & 1 & 3,33 \\
\hline & Jumlah & 30 & 100 \\
\hline
\end{tabular}

Sumber: Data Primer yang diolah, 2020

Untuk sistem upah dilakukan dengan Borongan, yaitu tergantung dari berapa unit barang yang mampu dihasilkan oleh pengrajin. Untuk setiap unit produk rata-rata dihargai $\mathrm{Rp}$ $20.000,00-\mathrm{Rp} 25.000,00$ tergantung tingkat kesulitannya. Sistem upah harian atau mingguan tidak diterapkan karena bisa mengakibatkan kerugian bagi pengusaha kalau upah yang diberikan tidak sesuai dengan hasil yang dikerjakan pengrajin.

\section{Deksripsi Data Variabel Penelitian}

Pada bagian ini disajikan deskripsi data dari tiap-tiap variabel yang diperoleh di lapangan. Berdasarkan data yang telah dikumpulkan, jawaban dari responden direkapitulasi dan kemudian dianalisis untuk mengetahui pengaruh modal kerja, nilai upah dan teknologi industri kerajinan serat agel terhadap penyerapan tenaga kerja di Desa Salamrejo, Kecamatan Sentolo, Kulon Progo. Berikut ini data secara rinci dari setiap variabel:

\section{a. Modal Kerja}

Modal kerja merujuk pada investasi perusahaan dalam bentuk aktiva lancar seperti kas, piutang, persediaan dan surat-surat berharga (Wibowo \& Wartini, 2013). Modal kerja industri kerajinan serat agel berbentuk kas dan persediaan bahan baku, piutang tidak dimasukan ke dalam analisis karena peneliti ingin mengetahui modal kerja minimum yang di pergunakan pada bulan Desember 2019 yang sudah tersedia secara tunai dan siap untuk dikeluarkan sewaktu-waktu. Data diperoleh dari jawaban pengusaha industri kerajinan serat agel mengenai kas perusahaan dan persediaan bahan baku (dalam rupiah). 
Tabel 4. Modal Kerja Pengusaha Industri Kerajinan Serat Agel Berupa Kas di Desa Salamrejo Pada Bulan Desember 2019

\begin{tabular}{|c|c|c|c|}
\hline No. & Kas & Frekuensi & $\begin{array}{c}\text { Persentase } \\
(\%)\end{array}$ \\
\hline 1. & $\begin{array}{c}1.050 .000 \\
-\end{array}$ & 26 & 86,67 \\
\hline 2. & $\begin{array}{c}14.150 .000 \\
-\end{array}$ & 0 & 0 \\
\hline 3. & $\begin{array}{c}27.450 .000 \\
- \\
40.550 .000\end{array}$ & 0 & 0 \\
\hline 4. & $\begin{array}{c}40.650 .000 \\
-\end{array}$ & 2 & 6,67 \\
\hline 5. & $\begin{array}{c}53.750 .000 \\
53.850 .000 \\
-\end{array}$ & 1 & 3,33 \\
\hline 6. & 66.950 .000 & & \\
\hline & $\begin{array}{c}67.050 .000 \\
-\end{array}$ & 1 & 3,33 \\
\hline & $\begin{array}{l}\text { Jumlah } \\
\text { Bumb. }\end{array}$ & 30 & 100 \\
\hline
\end{tabular}

Berdasarkan tabel 4, 30 pengusaha memiliki persediaan kas untuk bulan Desember 2019 lebih dari Rp 1.000.000,00, frekuensi persediaan kas terbesar berkisar antara $\mathrm{Rp}$. 1.050.000,00 - Rp. 14.150.000,00 yaitu sebesar $86,67 \%$ atau dimiliki oleh 26 pengusaha. Persediaan kas terbesar yaitu sebesar Rp. 80.500.000,00, sedangkan persediaan kas terkecil adalah sebesar Rp. 1.050.000,00.

Tabel 5. Modal Kerja Pengusaha Industri Kerajinan Serat Agel Berupa Persediaan Bahan Baku Pada Bulan Desember 2019

\begin{tabular}{|l|c|c|c|}
\hline $\begin{array}{c}\text { No } \\
\cdot\end{array}$ & $\begin{array}{c}\text { Persediaa } \\
\text { n Bahan } \\
\text { Baku } \\
\text { (Rupiah) }\end{array}$ & $\begin{array}{c}\text { Frekuens } \\
\text { i }\end{array}$ & $\begin{array}{c}\text { Persentas } \\
\text { e (\%) }\end{array}$ \\
\hline 1. & $\begin{array}{c}1.000 .000 \\
-\end{array}$ & 25 & 83,33 \\
& 9.000 .000 & & \\
\hline 2. & $\begin{array}{c}9.100 .000 \\
-\end{array}$ & 2 & 6,67 \\
& 17.100 .000 & & \\
\hline
\end{tabular}

\begin{tabular}{|l|c|c|c|}
\hline 3. & $\begin{array}{c}17.200 .000 \\
- \\
25.200 .000\end{array}$ & 1 & 3,33 \\
\hline 4. & $\begin{array}{c}25.300 .000 \\
-\end{array}$ & 0 & 0 \\
\hline 5. & $\begin{array}{c}33.300 .000 \\
-\end{array}$ & & \\
\hline 6.000 & 0 & 0 \\
\hline & $\begin{array}{c}41.400 .000 \\
-\end{array}$ & 2 & 6,67 \\
\hline & $\begin{array}{c}\text { Jumlah } \\
\text { Jumlan }\end{array}$ & 30 & 100 \\
\hline
\end{tabular}

Berdasarkan tabel 5, frekuensi persediaan bahan baku terbesar berkisar antara $\mathrm{Rp}$. 1.000.000,00 - Rp. 9.000.000,00 yaitu sebesar $83,33 \%$ atau dimiliki oleh 25 pengusaha.

Total modal kerja diperoleh dari penjumlahan kas dan persediaan bahan baku yang dimiliki pengusaha industri kerajinan serat agel pada Desember 2019.

Tabel 6. Total Modal Kerja Pengusaha Industri Kerajinan Serat Agel di Desa Salamrejo Pada Bulan Desember 2019

\begin{tabular}{|c|c|c|c|}
\hline No & Modal Kerja & Frekuensi & $\begin{array}{c}\text { Persentase } \\
(\boldsymbol{\%})\end{array}$ \\
\hline 1. & $3.250 .000-24.350 .000$ & 25 & 83,33 \\
\hline 2. & $24.450 .000-45.550 .000$ & 1 & 3,33 \\
\hline 3. & $45.650 .000-66.750 .000$ & 1 & 3,33 \\
\hline 4. & $66.850 .000-87.950 .000$ & 1 & 3,33 \\
\hline 5. & $88.050 .000-109.150 .000$ & 1 & 3,33 \\
\hline 6. & $109.250 .000-130.500 .000$ & 1 & 3,33 \\
\hline & Jumlah & 30 & 100 \\
\hline
\end{tabular}

Berdasarkan tabel 6, 30 pengusaha memiliki modal kerja lebih dari Rp. 3.000.000,00. Frekuensi kepemilikan modal kerja terbesar pada bulan Desember 2019 bekisar antara Rp. 3.250.000,00 - Rp. 24.350.000,00 yaitu sebesar 83,33\% atau dimiliki oleh 25 pengusaha. Modal kerja terbesar adalah Rp. 130.500.000,00 sedangkan modal kerja terkecil adalah Rp. 3.250.000,00.

b. Nilai Upah

Nilai Upah yang dimaksud adalah pengeluaran perusahaan untuk upah tenaga kerja pada bulan Desember 2019. Berdasarkan hasil pengumpulan data secara umum pengusaha industri kerajinan serat agel memberikan upah sebesar Rp. 25.000,00 untuk setiap unit barang yang diproduksi oleh tenaga kerja. 
Tabel 7. Pengeluaran Biaya Industri Kerajinan Serat Agel di Desa Salamrejo untuk Upah Tenaga Kerja Pada Desember 2019

\begin{tabular}{|c|c|c|c|}
\hline No & Upah Tenaga Kerja & Frekuensi & $\mathbf{( \% )}$ \\
\hline 1. & $200.000-10.000 .000$ & 26 & 86,67 \\
\hline 2. & $10.100 .000-19.900 .000$ & 0 & 0 \\
\hline 3. & $20.000 .000-29.800 .000$ & 1 & 3,33 \\
\hline 4. & $29.900 .000-39.700 .000$ & 0 & 0 \\
\hline 5. & $39.800 .000-49.600 .000$ & 1 & 3,33 \\
\hline 6. & $49.700 .000-60.000 .000$ & 2 & 6,67 \\
\hline & Jumlah & 30 & 100 \\
\hline
\end{tabular}

Berdasarkan tabel 7, 30 pengusaha industri kerajinan serat agel mengeluarkan biaya untuk upah tenaga kerja lebih dari Rp. 200.000,00. Frekuensi biiaya pengeluaran untuk upah tenaga kerja terbesar adalah berkisar antara Rp. 200.000,00 - Rp. 10.000.00,00 yaitu sebesar 86,67 \% atau dikeluarkan oleh 26 pengusaha industri kerajinan serat agel di Desa Salamrejo.

\section{c. Teknologi}

Kondisi teknologi saat ini merujuk pada cara bagaimana masukan ditransformasikan menjadi keluaran. Karena peralatan yang dipergunakan masih manual maka sulit untuk mengukur kapasitas barang yang di produksi, jadi ukuran yang dipergunakan untuk mengukur teknologi adalah biaya aplikasi teknologi (Fathul Wahid, 2007). Biaya aplikasi teknologi yang dimaksud adalah pengeluaran yang dikeluarkan oleh perusahaan dari penggunaan alat-alat untuk memproduksi barang pada bulan Desember 2019. Alat yang dipergunakan secara umum pada industri kerajinan serat agel di Desa Salamrejo meliputi alat rajut, mesin jahit, gunting, jarum, panci, pisau, kompresor, mesin gerinda, mesin potong logam, mesin bor.

Tabel 8. Biaya Aplikasi Teknologi Industri Kerajinan Serat Agel di Desa Salamrejo Pada Bulan Desember 2019

\begin{tabular}{|c|c|c|c|}
\hline No & $\begin{array}{c}\text { Biaya Aplikasi } \\
\text { Teknologi }\end{array}$ & Frekuensi & $\begin{array}{c}\text { Persentase } \\
(\mathbf{\%})\end{array}$ \\
\hline 1. & $10.000-90.600$ & 16 & 53,33 \\
\hline 2. & $91.600-172.200$ & 13 & 43,33 \\
\hline 3. & $173.200-253.800$ & 0 & 0 \\
\hline 4. & $254.800-335.400$ & 0 & 0 \\
\hline 5. & $336.400-408.000$ & 0 & 0 \\
\hline 6. & $418.000-500.000$ & 1 & 3,33 \\
\hline & Jumlah & 30 & 100 \\
\hline
\end{tabular}

Berdasarkan tabel 8, frekuensi terbesar biaya aplikasi teknologi adalah berkisar antara Rp. $10.000,00$ - Rp. $90.600,00$ yaitu $53,33 \%$ atau dikeluarkan oleh 16 pengusaha. Biaya pengeluaran untuk aplikasi teknologi terbesar adalah Rp. 500.000,00. Biaya pengeluaran untuk aplikasi teknologi terkecil adalah Rp. $10.000,00$.

\section{Pengujian Hipotesis}

a. Uji Parsial (Uji t).

Pengujian ini dilakukan untuk mengetahui keterkaitan atau pengaruh seluruh variabel independen (X1, X2, X3) secara individu dengan variabel dependen (Y). Untuk menguji signifikansi koefisien regresi digunakan t-hitung.

Tabel 9. Hasil Regresi Linear Berganda.

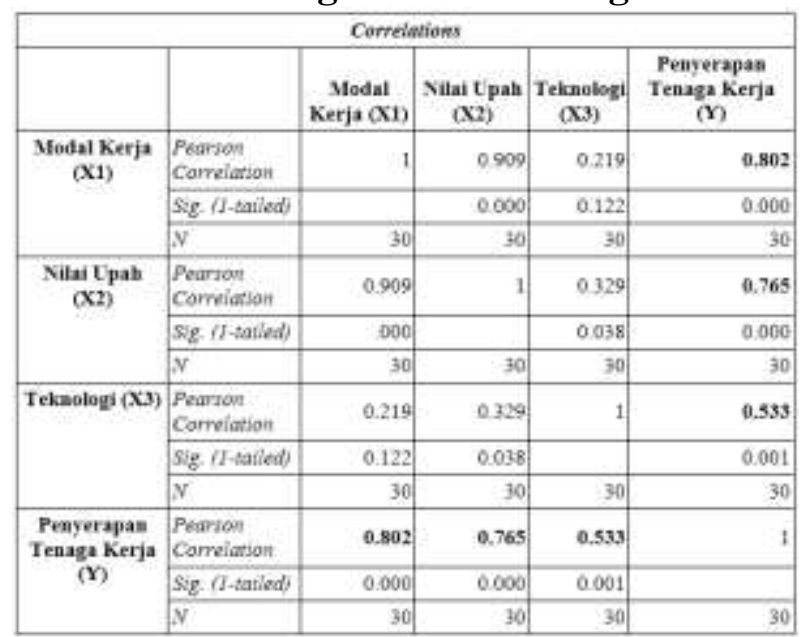

Adapun hasil uji hipotesis dalam penelitian ini adalah sebagai berikut:

1. Ada pengaruh positif dan signifikan antara modal kerja terhadap penyerapan tenaga kerja. Hal ini dibuktikan dengan koefisien korelasi parsial 0,802. Dengan adanya pengaruh yang positif ini, berarti bahwa antara variabel modal kerja dan penyerapan tenaga kerja menunjukkan hubungan yang searah. Jika variabel modal kerja semakin meningkat mengakibatkan penyerapan tenaga kerja akan meningkat, begitu pula sebaliknya. Signifikan karena nilai sig. $<0,05$.

2. Ada pengaruh positif antara nilai upah terhadap penyerapan tenaga kerja. Hal ini dibuktikan dengan koefisien korelasi parsial 0,765. Dengan adanya pengaruh yang positif ini, berarti bahwa antara variabel nilai upah dan 
penyerapan tenaga kerja menunjukkan hubungan yang searah. Jika variabel nilai upah semakin meningkat mengakibatkan penyerapan tenaga kerja akan meningkat, begitu pula sebaliknya. Signifikan karena karena nilai sig $<0,05$.

3. Ada pengaruh positif antara teknologi terhadap penyerapan tenaga kerja. Hal ini dibuktikan dengan koefisien korelasi parsial 0,533. Dengan adanya pengaruh yang positif ini, berarti bahwa antara variabel teknologi dan penyerapan tenaga kerja menunjukkan hubungan yang searah. Jika variabel teknologi semakin meningkat mengakibatkan penyerapan tenaga kerja akan meningkat, begitu pula sebaliknya. Signifikan karena nilai sig $<0,05$.

\section{b. Uji Silmutan (Uji F)}

Pengujian ini dilakukan untuk mengetahui apakah semua variabel independen secara bersama-sama (simultan) dapat berpengaruh terhadap variabel dependen. Uji F digunakan untuk menghitung besarnya perubahan nilai variabel dependen yang dapat dijelaskan oleh perubahan nilai semua variabel independen. Pengujian ini dilakukan dengan membandingkan nilai $\mathrm{F}$ hitung dengan $\mathrm{F}$ tabel (Wahid Sulaiman, 2004: 86). Prosedur yag dilakukan untuk melakukan uji $\mathrm{F}$ adalah sebagai berikut:

Tabel 10. Hasil Uji Simultan (Uji F)

\begin{tabular}{|c|c|c|c|c|c|}
\hline Variabel & $\begin{array}{c}\text { Koefisien } \\
\text { Korelasi } \\
\text { Parsial }\end{array}$ & $\mathbf{F}$ & $\begin{array}{c}\mathbf{F}_{\mathbf{0} 05} \\
\mathbf{( 3 ; 2 6})\end{array}$ & Sig. & Ket \\
\hline Konstanta & $-12,031$ & 30,375 & 2,980 & 0,000 & $\begin{array}{c}\text { Positif } \\
\text { Signifikan }\end{array}$ \\
\hline $\begin{array}{c}\text { Modal } \\
\text { Kerja } \\
\text { (X1) }\end{array}$ & 0,508 & & & 0,002 & $\begin{array}{c}\text { Positif } \\
\text { Signifikan }\end{array}$ \\
\hline $\begin{array}{c}\text { Nilai } \\
\text { Upah } \\
\text { (X2) }\end{array}$ & $-0,042$ & & & 0,737 & $\begin{array}{c}\text { Tidak } \\
\text { Berpengaruh }\end{array}$ \\
\hline $\begin{array}{c}\text { Teknologi } \\
\text { (X3) }\end{array}$ & 0,343 & & & 0,001 & $\begin{array}{c}\text { Positif } \\
\text { Signifikan }\end{array}$ \\
\hline
\end{tabular}

Untuk menginterpretasikan data diatas kembali ke hipotesis yang menyatakan:

Ho : Tidak ada pengaruh yang signifikan antara modal kerja, nilai upah dan teknologi secara simultan terhadap penyerapan tenaga kerja.

$\mathrm{Ha}$ : Ada pengaruh yang signifikan antara modal kerja, nilai upah dan teknologi secara simultan terhadap penyerapan tenaga kerja.

Jika $F_{\text {hitung }} \leq \mathrm{F}_{\text {tabel }}$ maka Ho diterima dan Hi ditolak

Dalam pengambilan keputusan ini dapat diperjelas dengan gambar sebagai berikut:

Gambar 3. Daerah Penerimaan dan Penolakan Ho Dengan Menggunakan Uji F

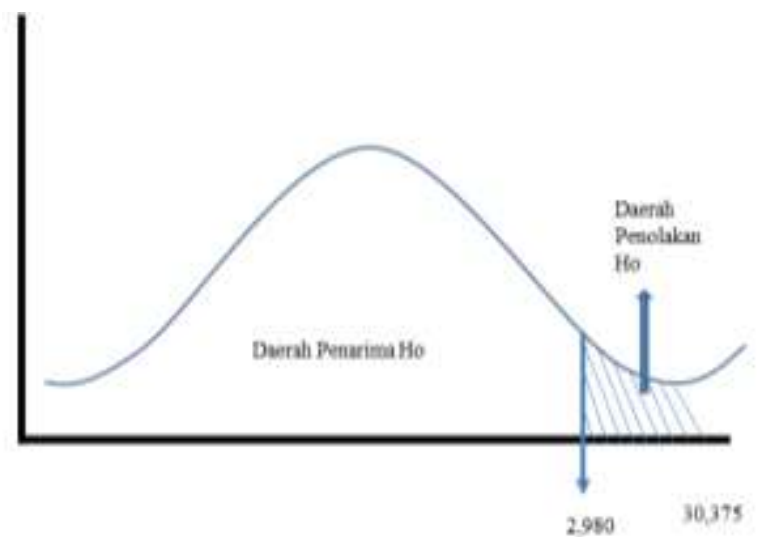

Dari tabel dapat dilihat bahwa $\mathrm{F}$ hitung 30,375 dengan taraf signifikansi $F_{\text {hitung }}$ sebesar 0,000 sedangkan $F_{\text {tabel }}$ sebesar 2,980. Hal ini menunjukkan bahwa $\mathrm{F}_{\text {hitung }}>\mathrm{F}$ tabel, maka Hi diterima dan Ho ditolak. Ini menunjukkan bahwa modal kerja, nilai upah dan teknologi mempunyai pengaruh positif dan signifikan terhadap penyerapan tenaga kerja.

Tabel 11. Pengaruh Modal Kerja, Nilai Upah dan Teknologi terhadap Penyerapan Tenaga Kerja di Desa Salamrejo Pada Desember Model Summary ${ }^{b}$

\begin{tabular}{|l|c|c|c|c|}
\hline Model & $\boldsymbol{R}$ & $\begin{array}{c}\boldsymbol{R} \\
\text { square }\end{array}$ & $\begin{array}{c}\text { Adjusted } \boldsymbol{R} \\
\text { Square }\end{array}$ & $\begin{array}{c}\text { Std. Error of the } \\
\text { estimate }\end{array}$ \\
\hline $\mathbf{1}$ & $\mathbf{0 , 8 8 2}^{\mathbf{a}}$ & $\mathbf{0 , 7 7 8}$ & $\mathbf{0 , 7 5 2}$ & $\mathbf{0 , 3 1 9 8 1}$ \\
\hline
\end{tabular}

a. Predictors: (Constant), Teknologi, Nilai Upah, Modal Kerja

b. Dependent Variabel: Penyerapan Tenaga Kerja

1) $R=0,882$ artinya koefisien korelasinya sebesar 0,882. Angka menunjukkan derajad korelasi antara variabel modal kerja, nilai upah, dan teknologi terhadap penyerapan tenaga kerja. 
2) $R$ Square $=0,778$ menunjukkan angka koefisien determinasinya $\left(\mathrm{R}^{2}\right)$. Artinya variansi dalam penyerapan tenaga kerja dapat dijelaskan oleh modal kerja, nilai upah dan teknologi melalui model sebesar $77,8 \%$, sisanya $22,2 \%$ berasal dari variabel lain. Atau dengan bahasa sederhana

besarnya kontribusi/sumbangan modal kerja, nilai upah dan teknologi terhadap penyerapan tenaga kerja adalah sebesar $77,8 \%$, sisanya $(22,2 \%)$ berasal dari variabel lain.

3) Adjusted $R$ square $=0,752$. Ukuran ini maknanya sama dengan $R$ square, hanya saja Adjusted R square ini nilainya lebih stabil karena sudah disesuaikan dengan jumlah variabel bebasnya.

4) Standard Error of The Estimate = 0,31981 yang menunjukkan ukuran tingkat kesalahan dalam melakukan prediksi terhadap variabel terikat.

Tabel 12. Sumbangan Relatif dan Sumbangan Efektif Modal Kerja, Nilai Upah dan Teknologi terhadap Penyerapan Tenaga Kerja di Desa Salamrejo Pada Desember 2019

\begin{tabular}{|c|l|c|c|}
\hline No. & $\begin{array}{l}\text { Variabel } \\
\text { Bebas }\end{array}$ & $\begin{array}{c}\text { Sumbangan } \\
\text { Relatif (\%) }\end{array}$ & $\begin{array}{c}\text { Sumbangan } \\
\text { Efektif (\%) }\end{array}$ \\
\hline 1. & $\begin{array}{l}\text { Modal } \\
\text { kerja } \\
\text { (X1) }\end{array}$ & 70.39 & 54.76 \\
\hline 2. & $\begin{array}{l}\text { Nilai } \\
\text { Upah } \\
(\mathrm{X} 2)\end{array}$ & 6.75 & 5.25 \\
\hline 3. & $\begin{array}{l}\text { Teknologi } \\
(\mathrm{X} 3)\end{array}$ & 22.86 & 17.79 \\
\hline \multicolumn{2}{|l|}{ Total } & 100.00 & 77.80 \\
\hline $\begin{array}{l}\text { Variabel } \\
\text { Terikat }\end{array}$ \\
\hline
\end{tabular}

Sumbangan relatif (SR) adalah perbandingan antara relatifitas yang diberikan satu variabel bebas terhadap variabel terikat dengan variabel bebas lain yang diteliti. Berdasarkan tabel 30, variabel modal kerja secara relatif berpengaruh terhadap penyerapan tenaga kerja sebesar 70,39\%. Variabel nilai upah secara relatif berpengaruh terhadap penyerapan tenaga kerja sebesar 6,75 \%. Sedangkan variabel teknologi secara relatif berpengaruh terhadap penyerapan tenaga kerja sebesar $22,86 \%$.

Sumbangan efektif (SE) adalah perbandingan efektifitas yang diberikan satu variabel bebas terhadap variabel terikat dengan variabel bebas lain yang diteliti maupun yang tidak diteliti. Berdasarkan tabel 12, variabel modal kerja secara efektif berpengaruh terhadap penyerapan tenaga kerja sebesar 54,76 $\%$. Variabel nilai upah secara efektif berpengaruh terhadap penyerapan tenaga kerja sebesar 5,25\%. Sedangkan variabel teknologi secara relatif berpengaruh terhadap penyerapan tenaga kerja sebesar 17,80 \%. Jadi, besarnya kontribusi/sumbangan modal kerja, nilai upah dan teknologi terhadap penyerapan tenaga kerja adalah sebesar $77,8 \%$, sisanya $(22,2 \%)$ berasal dari variabel lain yang tidak diteliti.

Tabel 13. Pengaruh Modal Kerja, Nilai Upah dan Teknologi terhadap Penyerapan Tenaga Kerja

\begin{tabular}{|c|c|c|c|c|c|c|}
\hline & & \multicolumn{5}{|c|}{$\mathbf{A N O V A}^{\mathbf{b}}$} \\
\hline $\begin{array}{c}\text { Mode } \\
\quad l\end{array}$ & & $\begin{array}{c}\text { Sum of } \\
\text { Square } \\
s\end{array}$ & $d f$ & $\begin{array}{c}\text { Mean } \\
\text { Squar } \\
e\end{array}$ & $\boldsymbol{F}$ & Sig. \\
\hline \multirow[t]{3}{*}{1} & $\begin{array}{l}\text { Regressio } \\
n\end{array}$ & 9,320 & 3 & 3,107 & $\begin{array}{c}30,37 \\
5\end{array}$ & $\begin{array}{l}0,000 \\
\mathrm{a}\end{array}$ \\
\hline & Residual & 2.659 & $\begin{array}{l}2 \\
6\end{array}$ & \multirow[t]{2}{*}{0,102} & & \\
\hline & Total & 11,979 & $\begin{array}{l}2 \\
9\end{array}$ & & & \\
\hline
\end{tabular}

a. Predictors: (Constant), Teknologi, Nilai Upah, Modal Kerja

b. Dependent Variabel: Penyerapan Tenaga Kerja

Bagian ini menampilkan hasil pengujian koefisien determinasi. Hasil pengujian tersebut ditemukan harga $\mathrm{F}$ hitung sebesar 30,375 dengan Sig. $=0,000$. Oleh karena nilai sig. < 0,05 maka Ho $(\rho=0)$ ditolak yang artinya modal kerja, nilai upah dan teknologi secara simultan memiliki pengaruh yang signifikan terhadap penyerapan tenaga kerja. 
Tabel 14. Pengaruh Modal Kerja, Nilai Upah dan Teknologi terhadap Penyerapan Tenaga Kerja

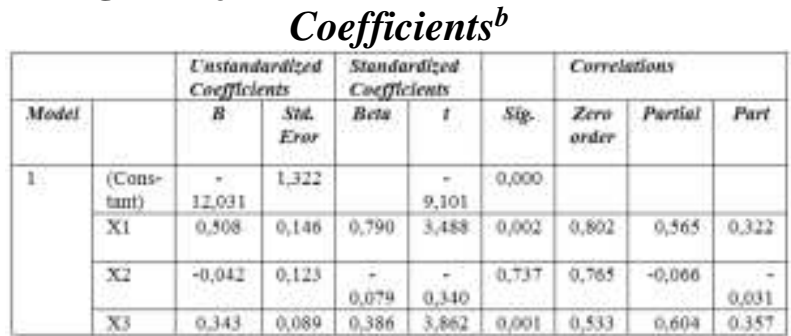

Dependent Variabel: Penyerapan Tenaga Kerja

Bagian ini menampilkan persamaan garis regresi dan pengujiannya. Persamaan garis regresi dapat diperoleh dari kolom Unstandardized Coefficients (B). Dengan demikian persamaan garis regresinya adalah: $Y^{\prime}=-12,031+0,508 X 1-0,042 X 2+0,343 X 3$

Untuk menguji koefisen garisnya dapat dilihat pada kolom $\mathrm{t}$ dan sig. Pengujian koefisien garis regresi dilakukan sebagai berikut:

1) Untuk variabel modal kerja (X1) ditemukan nilai $\mathrm{b} 1=0,508$ dengan $\mathrm{t}=$ 3,488 dan Sig. $=0,002$. Oleh karena nilai sig. $<0,05$ maka Ho $(\beta 1=0)$ ditolak yang artinya variabel modal kerja berpengaruh positif terhadap penyerapan tenaga kerja jika nilai upah dan teknologi tidak dikendalikan/dikontrol.

2) Untuk variabel nilai upah (X2) ditemukan nilai $\mathrm{b} 2=-0,042$ dengan $\mathrm{t}=$ $-0,340$ dan Sig. $=0,737$. Oleh karena nilai sig. $>0,05$ maka Ho $(\beta 2=0)$ diterima yang artinya variabel nilai upah tidak berpengaruh terhadap penyerapan tenaga kerja jika variabel modal kerja dan teknologi tidak dikendalikan/dikontrol.

3) Untuk variabel teknologi ditemukan nilai $\mathrm{b} 3=0,343$ dengan $\mathrm{t}=$ 3,862 dan Sig. $=0,001$. Oleh karena nilai sig. $<0,05$ maka Ho $(\beta 3=0)$ ditolak yang artinya variabel teknologi berpengaruh positif terhadap penyerapan tenaga kerja jika variabel modal kerja dan nilai upah tidak dikendalikan/dikontrol.
Pembahasan difokuskan pada penjelasan mengenai temuan penelitian yang sesuai dengan fakta di Desa Salamrejo dan teori yang dijadikan landasan dalam perumusan model penelitian. Sumbangan pengaruh variabel modal kerja (X1), nilai upah (X2) dan teknologi (X3) terhadap variabel penyerapan tenaga kerja (Y) secara simultan sebesar 0,778. Hal ini berarti bahwa $77,8 \%$ penyerapan tenaga kerja dapat dipengaruhi oleh variabel modal kerja, nilai upah dan teknologi. Sedangkan sisanya sebesar 22,2 \% dipengaruhi oleh variabel lain yang tidak diteliti. Adapun pembahasan untuk masing-masing hipotesis sebagai berikut:

1. Ada Pengaruh Positif dan Signifikan Antara Modal Kerja terhadap Penyerapan Tenaga Kerja di Desa Salamrejo Pada Bulan Desember 2019

Hal ini dibuktikan dengan koefisien korelasi parsial 0,802 , artinya antara variabel modal kerja dan penyerapan tenaga kerja menunjukkan hubungan yang searah. Jika variabel modal kerja semakin meningkat mengakibatkan penyerapan tenaga kerja akan meningkat, begitu pula sebaliknya. Signifikan karena nilai sig. $<0,05$. Hal ini dikarenakan semakin besar modal kerja yang dimiliki maka semakin besar pula kemampuan pengusaha utuk menyerap tenaga kerja sekitar. Besarnya sumbangan efektif modal kerja terhadap penyerapan tenaga kerja di Desa Salamrejo pada bulan Desember 2019 adalah 54,76 \% Hasil ini menunjukkan kesesuaian dengan hipotesis bahwa modal kerja berpengaruh positif dan signifikan terhadap penyerapan tenaga kerja.

2. Ada Pengaruh Positif dan Signifikan Antara Nilai Upah terhadap Penyerapan Tenaga Kerja di Desa Salamrejo Pada Desember 2019

Hal ini dibuktikan dengan koefisien korelasi parsial 0,765 , artinya antara variabel nilai upah dan penyerapan tenaga kerja menunjukkan hubungan yang searah. Jika variabel nilai upah semakin meningkat mengakibatkan penyerapan tenaga kerja juga akan meningkat, begitu pula sebaliknya. Signifikan karena nilai sig. <0,05. Besarnya sumbangan efektif nilai upah terhadap 
penyerapan tenaga kerja di Desa Salamrejo pada bulan Desember 2019 adalah 5,25\%. Hasil ini menunjukkan ketidaksesuaian dengan hipotesis bahwa nilai upah berpengaruh negatif dan signifikan terhadap penyerapan tenaga kerja. Ketidaksesuaian dengan hipotesis disebabkan karena data yang dihasilkan adalah data cross section pada bulan Desember 2019 dengan subyek penelitian 30 responden yang semuanya memiliki variasi data dan terpisah antara perusahaan yang satu dengan perusahaan yang lain. Variasi data tersebut apabila diregresikan menjadi positif karena pada perusahaan milik pengusaha I biaya pengeluaran bulan Desember untuk upah tenaga kerja sebesar Rp. 3.000.000,00 sedangkan jumlah tenaga kerja yang dimiliki adalah 13 orang sedangkan pada perusahaan II biaya pengeluaran bulan Desember untuk upah tenaga kerja sebesar Rp. 2.000.000,00 sedangkan jumlah tenaga kerja yang dimiliki adalah 11 orang dan begitu seterusnya. Pengeluaran upah yang besar dibarengi dengan jumlah tenaga kerja yang besar pula, pengeluaran upah kecil dibarengi dengan jumlah tenaga kerja yang sedikit sehingga hasilnya positif. Pada penelitian yang relevan hasilnya negatif karena data yang dipergunakan adalah time series dimana terjadi kontinuitas dari satu periode ke periode yang lain sehingga diketahui ada pengurangan tenaga kerja seiring dengan naiknya upah yang diberikan.Secara teoritik seharusnya dalam penelitian ini upah yang dipergunakan sebagai indikator untuk mengukur variabel adalah upah untuk harga tenaga kerja per unit produk dengan satuan per tenaga kerja karena sistem yang diberlakukan adalah borongan dan produknya heterogen.

3. Ada Pengaruh Positif dan Signifikan Antara Teknologi terhadap Penyerapan Tenaga Kerja di Desa Salamrejo Pada Desember 2019

Hal ini dibuktikan dengan koefisien korelasi parsial 0,533 , artinya antara variabel teknologi dan penyerapan tenaga kerja menunjukkan hubungan yang searah. Jika variabel teknologi semakin meningkat mengakibatkan penyerapan tenaga kerja akan meningkat, begitu pula sebaliknya. Signifikan karena nilai sig. $<0,05$. Besarnya sumbangan efektif teknologi terhadap penyerapan tenaga kerja di Desa Salamrejo pada bulan Desember 2019 adalah 17,79 \%. Hal ini membuktikan semakin besar biaya aplikasi penggunaan peralatan yang dikeluarkan oleh pengusaha semakin besar pula tenaga kerja yang mampu diserap. Hasil ini menunjukkan ketidaksesuaian dengan hipotesis yang menyatakan bahwa teknologi industri berpengaruh negatif dan signifikan terhadap penyerapan tenaga kerja. Hal ini dikarenakan teknologi yang dipergunakan sangat melekat pada tenaga kerja, sehingga peningkatan biaya untuk pengadaaan alat-alat juga dibarengi dengan peningkatan tenaga kerja karena setiap tenaga kerja mempergunakan alat-alat tersebut.

4. Ada Pengaruh Positif dan Signifikan Antara Modal kerja, Nilai upah dan Teknologi Secara Simultan terhadap Penyerapan Tenaga Kerja di Desa Salamrejo Pada Desember 2019

Hal ini dibuktikan dengan hasil pengujian koefisien determinasi. Hasil pengujian tersebut ditemukan harga $\mathrm{F}$ hitung sebesar 30,375 dengan Sig. = 0,000 . Oleh karena nilai sig. $<0,05$ maka Ho $(\rho=0)$ ditolak yang artinya modal kerja, nilai upah dan teknologi secara simultan memiliki pengaruh yang positif dan signifikan terhadap penyerapan tenaga kerja. Besarnya sumbangan efektif modal kerja, nilai upah dan teknologi secara simultan terhadap penyerapan tenaga kerja adalah sebesar 77,80 \%. Hasil ini menunjukkan kesesuaian dengan hipotesis.

\section{PENUTUP}

\section{Kesimpulan}

Terdapat pengaruh positif dan signifikan antara modal kerja terhadap penyerapan tenaga kerja di Desa Salamrejo pada Desember 2019. Terdapat pengaruh positif dan signifikan antara nilai upah terhadap penyerapan tenaga kerja di Desa Salamrejo pada Desember 2019. Terdapat pengaruh positif dan signifikan antara teknologi terhadap penyerapan tenaga kerja di Desa Salamrejo pada Desember 2019. Terdapat pengaruh positif dan signifikan antara modal kerja, nilai upah dan teknologi secara simultan terhadap penyerapan 
tenaga kerja di Desa Salamrejo pada Desember 2019. Peningkatan modal kerja perlu dilakukan karena modal kerja berpengaruh terhadap penyerapan tenaga kerja sekaligus sebagai upaya peningkatan pendapatan. Diharapkan pemerintah ikut berperan serta untuk memberikan pinjaman modal kepada industri kecil dengan syarat-syarat yang tidak memberatkan bagi industri kecil. Pemerintah juga sebaiknya berperan mewujudkan program kemitraan yang baik antara pengusaha besar, koperasi, perbankan maupun sesama industri kecil dan menengah.

\section{Saran}

Ada beberapa pilihan yang bisa dicoba pengusaha industri kerajinan serat agel dalam meningkatkan modal kerja, yaitu: Pengusaha kerajinan serat agel bisa mengajukan Kredit Usaha Rakyat (KUR) yang disediakan oleh pemerintah untuk usaha kecil yang membutuhkan bantuan dana atau modal guna mengembangkan usahanya. Pengusaha kerajinan serat agel bisa mengajukan proposal ke DISPERINDAG untuk mengajukan dana hibah guna meningkatkan modal kerja. Pengusaha kerajinan serat agel juga bisa mengajukan Program Nasional Pemberdayaan Masyarakat (PNPM) Mandiri. Kepada Pemerintah Daerah Kabupaten Kulon Progo agar lebih berhatihati dalam menaikkan standar upah minimum karena justru akan menambah pengangguran. Hal ini juga perlu diperhatikan oleh para pemilik usaha kerajinan serat agel di Salamrejo karena upah merupakan salah satu bagian dari biaya produksi bagi usaha mereka, sehingga kenaikan upah membuat biaya produksi mereka meningkat dan harus mengurangi jumlah tenaga kerja. Diharapkan pemerintah ikut andil dalam meningkatkan alat teknologi dan pemuktahiran alat untuk produksi kerajinan tetapi juga memberikan pelatihan pelatihan kepada pengrajin industri kerajinan khususnya dalam keterampilan penggunaan dan pemeliharaan alat.

\section{DAFTAR PUSTAKA}

[1] Azlina, N. (2012). Pengaruh Tingkat Perputaran Modal Kerja, Struktur Modal Dan Skala Perusahaan Terhadap Profitabilitas. PEKBIS ( Jurnal Pendidikan Ekonomi Dan Bisnis ), 1(02). Retrieved from

https://pekbis.ejournal.unri.ac.id/index.ph p/JPEB/article/view/373
[2] Dimas, N. W. (2009). Penyerapan Tenaga Kerja Di Dki Jakarta. Jurnal Bisnis Dan Ekonomi, 16(1), 32-41.

[3] Fathul Wahid, L. I. (2007). Adopsi Teknologi Informasi Oleh Usaha Kecil Dan Menengah Di Indonesia Fathul. Seminar Nasional Aplikasi Teknologi Informasi 2007 (SNATI 2007), 2007(Snati), 75-79. Retrieved from http://journal.uii.ac.id/index.php/Snati/arti cle/viewFile/1732/1512

[4] Indraswati, D., Hidayati, V. R., Wulandari, N. P., \& Maulyda, M. A. (2020). Pengaruh Penggunaan Media Sosial Dan Lingkungan Keluarga Terhadap Minat Berwirausaha Mahasiswa Pgsd Universitas Mataram. Jurnal Ekonomi Pendidikan Dan Kewirausahaan, $9(1), \quad$ 17-34. https://doi.org/10.26740/JEPK.V9N1.P1734

[5] Nurin Haq Swarsingkin, S. R. B. (2015). Studi Komparatif Industri Kerajinan Serat Alam Kabupaten Bantul Dan Kabupaten Kulonprogo. Jurnal Bumi Indonesia, 4(1), 120-128.

[6] Oktafia, R. (2017). Percepatan Pertumbuhan Usaha Mikro, Kecil dan Menengah (UMKM) Melalui Perkuatan Lembaga Keuangan Mikro Syariah (LKMS) di Jawa Timur. Proceedings of Annual Conference for Muslim Scholars, (Seri 1), 85-92. Retrieved from http://proceedings.kopertais4.or.id/index.p hp/ancoms/article/view/11

[7] Pandansari, A., Handajani, R. P., \& Pamungkas, S. T. (2015). Penggunaan Material Serat Alam pada Interior Ruang Pamer Galeri Seni Kerajinan di SalamrejoYogyakarta Ayu. Jurnal Mahasisswa Jurusan Arsitektur, 3(4), 1-6.

[8] Putra, R. E. (2012). Pengaruh Nilai Investasi, Nilai Upah, Dan Nilai Produksi Terhadap Penyerapan Tenaga Kerja Pada Industri Mebel Di Kecamatan Pedurungan Kota Semarang. Economics Development Analysis Journal, 1(2). https://doi.org/10.15294/edaj.v1i2.484

[9] Putri, A. F., \& Kesumajaya, I. W. W. (2017). Analisis Pengaruh Modal, Tingkat 
Upah Dan Teknologi Terhadap Penyerapan Tenaga Kerja Serta Produksi Pada Industri Kerajinan Batako. E-Jurnal EP UNUD. Universitas Udayana, 6(3), 26. Retrieved from https://ojs.unud.ac.id/index.php/eep/article /view/27795

[10]Rudiantoro, R., \& Siregar, S. V. (2012). Kualitas Laporan Keuangan Umkm Serta Prospek Implementasi Sak Etap. In Kualitas Laporan Keuangan UMKM serta... 1 Jurnal Akuntansi dan Keuangan Indonesia (Vol. 9). Retrieved from http://jaki.ui.ac.id/index.php/home/article/ view/141

[11] Sappaile, B. I. (2010). Konsep Penelitian Ex-Post Facto. Jurnal Pendidikan Matematika, 1(2).

[12] Setyowati, E. (2009). Analisis Tingkat Partisipasi Wanita Dalam Angkatan Kerja Di Jawa Tengah Periode Tahun 19822000. Jurnal Ekonomi Pembangunan: Kajian Masalah Ekonomi Dan Pembangunan, $10(2), \quad 215$. https://doi.org/10.23917/jep.v10i2.801

[13] Suci, Y. R. (2017). Perkembangan Umkm (Usaha Mikro Kecil Dan Menengah) Di Indonesia. Jurnal Ilmiah Cano Ekonomos, 6(1).

[14] Sumarno, M. (2010). Tingkat Adopsi Inovasi Teknologi Pengusaha Sentra Industri Kecil Kerajinan Gerabah Kasongan Kabupaten Bantul. Jurnal Manajemen Dan Kewirausahaan, 12(1), $1-10$.

https://doi.org/10.9744/jmk.12.1.pp.1-10

[15]Wibowo, A., \& Wartini, S. (2013). Efisiensi Modal Kerja, Likuiditas Dan Leverage Terhadap Profitabilitas Pada Perusahaan Manufaktur Di BEI. Jurnal Dinamika Manajemen, 3(1), 49-58. https://doi.org/10.15294/jdm.v3i1.2459

[16] Widiastuti, R* ; Awang, S.A**; Prayitno, T.A. **, Warsito, S. P. **. (2011). Kajian Stratejik Kelola Usaha Pada Industri Kecil Agel Strategic Study Of Business Manage In Agel Small Industries. Jurnal Riset Industri, V(1), 1-11. 


\section{HALAMAN INI SENGAJA DIKOSONGKAN}

